\title{
GEO-TOURISM LAND SUITABILITY ANALYSIS OF CITATAH KARST AREA IN BANDUNG BASIN USING SPATIAL MULTI CRITERIA EVALUATION (SMCE)
}

\author{
Nendi ROHAENDI* \\ University of Padjadjaran (UNPAD), Human Resources Agency of Energy and Mineral Resources, \\ Ministry of Energy and Mineral Resources of Indonesia, Jatinangor, Indonesia, e-mail: nendis@ gmail.com \\ Emi SUKIYAH \\ University of Padjadjaran (UNPAD), Department of Geosciences, Jatinangor, Indonesia, e-mail: emi.sukiyah@unpad.ac.id \\ Dicky MUSLIM \\ University of Padjadjaran (UNPAD), Department of Applied Geology, Jatinangor, Indonesia, e-mail: d.muslim@unpad.ac.id
}

Athanasius CIPTA

Geological Agency, Ministry of Energy and Mineral Resources of Indonesia, e-mail: ciptito@gmail.com

\begin{abstract}
Citation: Rohaendi, N., Sukiyah, E., Muslim, D., \& Cipta, A. (2021). GEO-TOURISM LAND SUITABILITY ANALYSIS OF CITATAH KARST AREA IN BANDUNG BASIN USING SPATIAL MULTI CRITERIA EVALUATION (SMCE). GeoJournal of Tourism and Geosites, 39(4spl), 1346-1353. https://doi.org/10.30892/gtg.394spl04-777
\end{abstract}

\begin{abstract}
The research goal is to evaluate land suitability for geo-tourism focuses on geology and landscape. Most of the Citatah karst area is natural-based industries or mining in particular. The ecological disturbance is an impetus for decision-makers to choose new use of land to deal with the conservation issues. SMCE techniques that apply geographic information systems (GIS) and analytical hierarchy processes. The use of land is formulated based on policy and stakeholder analysis. The research benefit is the possibility to change the area from mining to a geo-tourism area. There are two important results of research in spatial analysis, namely: intensive and extensive tourism areas, and the rest is for protective or no suitable area of tourism. In conclusion, the land suitability analysis is important for tourism industry development.
\end{abstract}

Key words: Geo-tourism; SMCE; GIS; Citatah Karst Area; Land Suitability evaluation

\section{INTRODUCTION}

Geo-tourism is a relatively new form of nature tourism that specifically focuses on geology and landscape as tourist attractions. Since the Indonesian geopark movement in 2010, geo-tourism has been one of the most rapid-growing market segments within the tourism industry in Indonesia (Cahyadi and Newsome, 2020). The goals of geo-tourism are to visit geosites, conserve geo-diversity, understand earth sciences, and appreciate nature. These goals can be achieved through independent or a guided tour visiting geological feature sites, walking geo-trails, doing geological activities, or conserving geological sites (Dowling, 2011; Newsome et al., 2012; Ólafsdóttir, 2018). Geo-tourism is closely related to ecotourism and cultural tourism (Dowling, 2013), the link between geo-tourism and ecotourism can be done through learning about nature, passive activities such as geo-tourism routes, and appreciation of flora and fauna. Furthermore, the relationship between geo-tourism and cultural tourism can be inferred, for example, when the local community uses geological materials forming the arts or cultural tools from the rocks. In addition, geo-tourism also has a relationship with adventure tourism that makes geological features a place for mountain climbing, rock climbing, or other extreme sports activities.

The fastest growth of geo-tourism worldwide is related to the increasing number of memberships of the UNESCO Global Geopark Network (Ólafsdóttir, 2019). Karsts are key issues in the study of geo-heritage and geo-tourism, many of protected karst are important parts of geoparks (Ruban, 2018). Karst is a terrain which characterizes by special landforms and drainage patterns, owing to its greater solubility of certain rocks in natural waters than the others (Urich, 2002). Karst is generally composed of limestones characterized by subterranean drainage, caves, and closed depressions. Karst generally has low porosity and temporary low water storage due to its rock characteristics, allowing water to flow through cavities and cracks, soil overlying the karst may store water longer. In present Spatial Plan Law No.26/2007, geological conservation area come as priority before development area. Furthermore, the conservationist urged that the Citatah karst area (CKA) should be protected as Citatah geopark. Citatah karst area is the area where the exokarst and endokarst are exist as a representative of karstification. Those have a function as cultural and geological heritage, groundwater recharge area, natural water storage (aquifer), and permanent springs. The research aims to evaluate land suitability of karst landform and other limestones formation in Citatah karst area for geo-tourism using spatial multi criteria evaluation (SMCE) to recommend a karst management that suitable for this area. SMCE already applied for cropping pattern

\footnotetext{
* Corresponding author
} 
planning (Rahman and Saha, 2008), landfill site selection (Gorsevski et al., 2012), land suitability analysis for wheat (Sarkar et al., 2014), site suitability for marina construction (Gumusay et al., 2016), foot sport orienteering (Tutic et al., 2018), tourism (Ebrahimi et al., 2019), and land suitability analysis for maize (Habibie et al., 2019)

\section{STUDY AREA}

There are four main cities/regencies in Greater Bandung, including Bandung, Cimahi, West Bandung regency, and Bandung regency, which formed Bandung Metropolitan Area (BMA) (Tarigan et al., 2016). The BMA offers culture, education, and nature as its main attraction (Figure 1). In addition, shopping tourism, and MICE (Meeting, Incentive, Conference, Exhibition) events, and also knowledge-based tourism is rapidly growing. Citatah karst area (CKA) is located in West Bandung regency about $120 \mathrm{~km}$ from Jakarta and $20 \mathrm{~km}$ from Bandung. Citatah Karst Area is located in western part of Bandung basin that extending from Cimahi-Batujajar to Cililin and Saguling dam. Bandung basin is an intermontane basin surrounded by tertiary volcanic and mountain ranges that has many geo-tourism sites on one hand, and potential hazards on other hand (Rohaendi et al., 2021). The total area of Bandung basin is $2300 \mathrm{~km}^{2}$, spans $60 \mathrm{~km}$ and $40 \mathrm{~km}$ in west-east and north-south directions, respectively, covering an area from elevation $650 \mathrm{~m}$ above sea level to peak about $2400 \mathrm{~m}$ high the late tertiary volcanic range. CKA has a strategic position because as the main gate for people who travel from Jakarta to Bandung. However, the area of karst is exploited as the mining industry. For a sustainable reason, the administration of West Bandung desires to change CKA from a mining industrial-based city to a natural tourismbased city. Currently, closed to Citatah, there are geology-based tourism such as Ciburuy lake, stone garden, and Pawon cave, which are also famous for an extreme sport such as rock climbing and orienteering (Wulung et al., 2019).

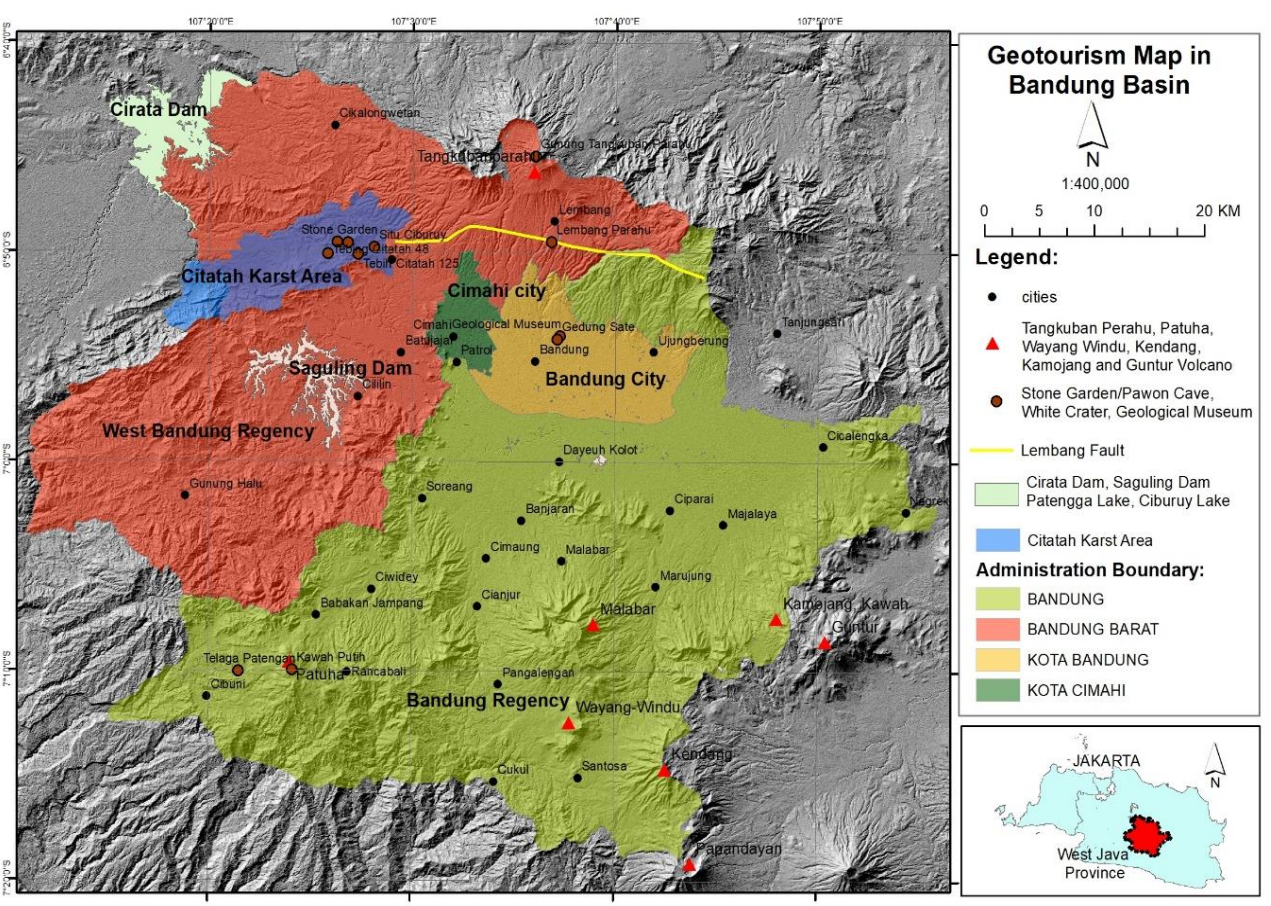

Figure 1. Some of famous geo-tourism site in Bandung basin: Lembang fault zone, volcanos, dormant volcanic crater, hot springs, natural lakes, and geothermal area (Source: DEMNAS -Geospatial Information Agency of Indonesia)

\section{MATERIALS AND METHODS}

The determination of appropriate land use for CKA is assessed by Spatial Multi Criteria Evaluation using Ilwis 3.8.2, an open-source software developed by ITC Enscede, Netherland. This method includes problem structuring, standardization, weighing, suitability assessment, and location identification. Stakeholders are involved in problem identification, land use alternatives development, criteria selection, and weighing process. Land use alternatives and criteria of evaluation are formulated from literature review, policy, and stakeholder analyses. SMCE is applied to identify or design potential areas, which are biophysically and in proximity suitable for

future land use categories.

SMCE is exploited to evaluate potential sites considering economic, social, and environmental suitability. Here each point/pixel in the map is considered as a potential element of a site. The development of criteria structure for the design of suitability analysis in the study area is formulated by considering the policies analysis and stakeholder analysis.

\section{a. Policy Analysis}

Based on government regulation No. 26/2008 (No.13/2017) about National Spatial Plan, in article 53 (b) the uniqueness of karst landform is part of geological conservation, which is an important part of national natural conservation. As consequence, the provincial government of West Java released regulation No. 22/2010 regarding spatial planning of West Java province from 2009 to 2029. It concerns the protection of Citatah karst area. It is followed by regulation from West Bandung regency about a spatial plan from 2009 to 2029 and regulation of west Bandung mayor No. 7/2010 about the protection of Pawon cave site and surrounding area. In the end, there is a master plan of Citatah karst area in 2010 from the agency of environmental protection management of west Java province (Figure 2).

To assist provincial and local governments, Ministry of Energy and Mineral Resources Regulation No. 17/2012 was released, as guidance for designing a spatial plan in a karst region. This regulation straightforwardly assigned the karst region as a geological protected area and part of the national protected area. This regulation encourages provincial and local governments to more actively protect the karst landscape in their region. 


\section{b. Stakeholder Analysis}

Stakeholder analysis is designed to accommodate all parties interested in the planning and decision-making process. Stakeholders, any group or individual, can be affected either directly or indirectly by the decision-making process or the achievement of the organization's objectives (Bryson, 2007). The land use development model is not developed with a topdown approach but a more participatory exercise where stakeholders will provide some inputs to make a decision model. The participation of stakeholders signals how the public involves in the environmental decision-making process (Beierle, 2002). Public participation is an important component and tool for improving knowledge of the problem and not for receiving inputs to be used uncritically in the evaluation (Munda, 2004). Stakeholder selection for the study area is defined by literature review, discussion with local planners, and some factors such as time, expertise, representation, and access to stakeholders. (Aryantie and Suhirman, 2019). Some stakeholders are involved in decision-making as follows; central and local government, geological and mining experts (academic), mining companies, and community representatives (Table 1).

Table 1. Stakeholder Selection from

Literature review and Discussion

\begin{tabular}{|l|l|l|}
\hline No & Stakeholder & \multicolumn{1}{|c|}{ Representatives } \\
\hline 1 & $\begin{array}{l}\text { Central } \\
\text { Government }\end{array}$ & $\begin{array}{l}\text { Geological Agency of Indonesia, Ministry } \\
\text { of Environmental, Ministry of Public Work }\end{array}$ \\
\hline 2 & $\begin{array}{l}\text { Local } \\
\text { Government }\end{array}$ & $\begin{array}{l}\text { Archaeology Agency of Bandung, Energy } \\
\text { and Mineral Resources Agency of West } \\
\text { Java Province, Environmental Management } \\
\text { Agency of west Java Province, } \\
\text { Development Planning Agency of west } \\
\text { Java Province, Department of Highways } \\
\text { and Irrigation west Bandung Regency, } \\
\text { Environmental Office of west Bandung } \\
\text { regency, Regional Development Planning } \\
\text { Agency of west Bandung Regency. }\end{array}$ \\
\hline 3 & Company & $\begin{array}{l}\text { State owned company of Perhutani KPH } \\
\text { south Bandung, Citatah Miners Association }\end{array}$ \\
\hline 4 & Academic & $\begin{array}{l}\text { Bandung basin research group, ITB, } \\
\text { UNPAD. }\end{array}$ \\
\hline 5 & Community & $\begin{array}{l}\text { Cultural institutes of west Bandung, } \\
\text { Tourism Awareness Group }\end{array}$ \\
\hline
\end{tabular}

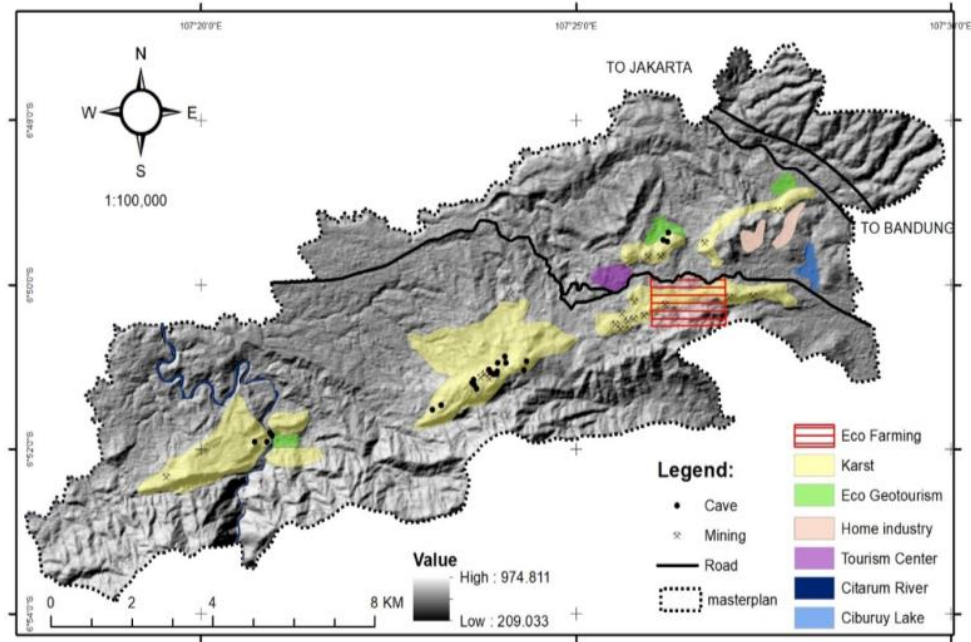

Figure 2. Master plan of Citatah karst area according to Government of West Java Province (Source: DEMNAS -Geospatial Information Agency of Indonesia)

\section{c. Multi Criteria Evaluation (MCE) and Analytical Hierarchy Process (AHP)}

Based on policy analysis and stakeholder analysis, there are two main objectives for suitability analysis for the study area including restoration of former mining land and accommodating new development of land use. The development of tourism areas is to provide job opportunities as new economic activities. Tourism has multiplier effects to encourage other sectors such as small industries and restaurants. In this case, land suitability evaluation was applied to determine the suitable location for the protected area (ecotourism), intensive geo-tourism area, extensive geo-tourism area, and extreme sport area. The protected area is can be used for ecotourism area and orienteering sport, the intensive geo-tourism area is geological based tourism that can be combined with other facilities such as shopping center, museum, or MICE, the extensive geo-tourism area is geological based tourism with the only focus on depth knowledge of geology and geomorphology, and extreme sport area is the place for an extreme sport such as rock climbing. To make spatial multi criteria evaluation possible, there are ten factors as inputs layers. The input layers are standardized from their original values to the value range of $0-1$. The input maps have different measurement scales (nominal, ordinal, interval, dan ratio). The map is converted as pixel raster-based maps. SMCE module of ILWIS has different standardization methods such as concave, convex, maximum, interval, and goal. The weighting method is applied to an underlying nine-point recording scale to rate the relative preference on a one-to-one basis of each factor (Saaty, 1987). The scale used in analytical hierarchy studies is ranging from 1 (equal importance or indifference) to 9 (absolute importance or extreme preference). The nine points rating scale also has qualitative expression related to quantitative values (Table 2).

Tabel 2. The verbal statements judgement scale for paired comparison (Saaty, 1980)

\begin{tabular}{|l|l|}
\hline $\begin{array}{c}\text { Numerica } \\
\text { I Value }\end{array}$ & $\begin{array}{c}\text { The importance of } \\
\text { parameters relative to } \\
\text { each other }\end{array}$ \\
\hline 1 & Equal importance \\
\hline 3 & More relatively importance \\
\hline 5 & More importance \\
\hline 7 & Much more importance \\
\hline 9 & So much importance \\
\hline $2,4,6,8$ & The importance of intervals \\
\hline
\end{tabular}

Table 3. The effective factors for land suitability evaluation of geo-tourism

\begin{tabular}{|l|l|l|l|}
\hline No & \multicolumn{1}{|c|}{ Factor } & \multicolumn{1}{c|}{ Measurements } & \multicolumn{1}{c|}{ Source } \\
\hline 1 & Elevation & Classes of elevation heights in meter & DEMNAS (GIA) \\
\hline 2 & Slope & Classes of land slopes in percentage & DEMNAS (GIA) \\
\hline 3 & Aspect & Geographical slope direction of each land unit & DEMNAS (GIA) \\
\hline 4 & Soil Biomes & Geomorphic phenomena in each soil unit & Map Analysis \\
\hline 5 & Geology & Main units of each geo-form and landform & Geological Agency of Indonesia \\
\hline 6 & Land cover & Main types of land covers & GIA \\
\hline 7 & $\begin{array}{l}\text { Ground } \\
\text { water }\end{array}$ & $\begin{array}{l}\text { Hydrological potentials of water discharge in } \\
\text { each landform }\end{array}$ & $\begin{array}{l}\text { Geological Agency of } \\
\text { Indonesia }\end{array}$ \\
\hline 8 & Main road & Distance from main road in meter & Topography map (GIA) \\
\hline 9 & Fault & Distance from fault in meter & Geological Agency of Indonesia \\
\hline 10 & River & Distance from main river in meter & Topography map (GIA) \\
\hline
\end{tabular}

The overlay of factor maps will use to produce Geo-tourism-based land suitability analysis, as a sum combination of all raster data layers. In this study, the ten-factor map layers were multiplied by the weight value individually, then all factors 
and their classes were overlaid to result in a suitability map. The value of weight $\left(\mathrm{W}_{\mathrm{ix}}\right)$ is calculated based on the eigenvector associated with the maximum absolute eigenvalue. Consistency index is used to analyze the consistency of judgment using the equation below (Masih et al., 2018, Ebrahimi et al., 2019,);

$S=\sum_{x=1}^{n} W_{i x} X U_{i x y} \quad$ (1) where, $\mathrm{S}=$ suitability index of each cell, $\mathrm{W}_{\mathrm{ix}}=$ weight of factor $\mathrm{x}$ in the pixel unit $\mathrm{i}$, and $\mathrm{U}_{\text {ix' }}=$ criterion score of factor $\mathrm{x}$ in the unit pixel $\mathrm{i}$
$C I=\frac{(\max -n)}{(n-1)}$
$C R=\frac{G I}{R I}$
where, $\mathrm{CI}=$ consistency index, $\mathrm{n}=$ the number of criteria, $\boldsymbol{\lambda}_{\max }=$ the largest eigen value
where, $\mathrm{CR}$ : consistency ratio, $\mathrm{CI}$ : consistency index, $\mathrm{RI}$ : random index

\section{RESULTS AND DISCUSSION}

The result of the suitability analysis of CKA using SMCE will be presented in the sub section of land suitability evaluation. Then, the proposed development of geo-tourism of CKA will be discussed in sub section development of geo-tourism area.

\section{Land Suitability Evaluation}

Citatah karst area has two main functions; built-up and conservation area. As the built-up (development) area, many mining companies operating for many years as the main source of economic development, and some mining areas have started a post-mining land use program. Based on stakeholder preferences analysis to develop the area as a geo-tourism area and the availability of the data for land suitability analysis, and notably by Ebrahimi et al. (2019) the most significant biophysical criteria for geo-tourism are elevation, slope, aspect, land use/cover, soil, geology, groundwater, distance from the main road, distance from the fault, and distance from the river. The main source of factors for GIS layers for elevation, slope, and aspect are DEMNAS (Digital Elevation Model National) with a spatial resolution of about $8 \times 8 \mathrm{~m}$ and topography maps from Geospatial Information Agency of Indonesia (GIA) and GIS layer for geology and groundwater (hydrogeology) from Geological Agency of Indonesia (GAI) as presented in Table 3.

The elevation data show that the study area is ranging from 209 to $975 \mathrm{msl}$. Nearly $25 \%$ of the region above $750 \mathrm{msl}$. The high elevation is located in the southern and western parts of the study area (Figure 3a). The slope map of the study area is classified from $<5$ to $>15 \%$, where most of the region $(80 \%)$ belong to slope class more than $15 \%$ with low or medium suitability for any spatial development (Figure 3b). The aspect as the direction of maximum slope of terrain surface was created using GIS, the sunny slopes as an aspect of $22.5^{\circ}-157.5^{\circ}$ (figure $3 \mathrm{c}$ ). Soil biome is defined based on the soil texture and geomorphic patterns in each soil unit. There are sedimentary slopes, volcanic slopes, alluvium, and lake bottom (Figure 3d).

Karst Citatah-Rajamandala area is prominent morphology of 42 hills of karst which occurred on limestones of Rajamandala formation (Figure 3e). Based on Sudjatmiko (1972), the geological unit the study area from the oldest to the youngest is andesite basalt, followed by limestone member of Rajamandala Formation (Oml), as solid limestone thus layered limestone, which is generally light-colored with big abundant foraminifera. After that, there are the clay, marl, and quartz sandstone of Rajamandala formation (Omc). Then, there is limestone and claystone member of Cantayan Formation (Mttl) and (Mttc). Lastly, there are sediment rocks from Citarum formation (Mtb and Mts) such as tuffaceous breccia, lava, sandstone, conglomerate, and siltstone. The youngest are volcanic quaternary rocks such as breccia, lava, volcanic-breccia lava, flow-breccia, lava sediment, and lava that shows out the plates and many arrangements between andesite and basalt. The groundwater of the study area based on hydrogeology map (Pasaribu et al., 1998) is divided into two classes: non aquifer and aquifer with well yield less than 5 liters/sec (Figure 3f). The geological structure of the Citatah karst area is one of the segments of the big Cimandiri fault system (Figure 3i). The dominant land cover is plantation about $29 \%$ of the total area, followed by grassland and shrubs about 23 and $22 \%$ of the total area respectively. The paddy fields, forest, and vacant land are covered about $14 \%$ of the total area, and the rest is built-up area about $12 \%$ of the total area. The mining area is occupied about 340 hectares of the total area or about $3 \%$ of the total area (Figure $3 \mathrm{~g}$ ). In the western part of the area, there is Citarum river, one of the biggest rivers in west Java. Considering as ancient Citarum area, this area is very important to be protected as a vulnerable area (Figure 3h). The main road crossing the Citatah karst area is the national road and toll road (Figure $3 \mathrm{j}$ ). Considering the accessibility of the location is very important to tourism area.
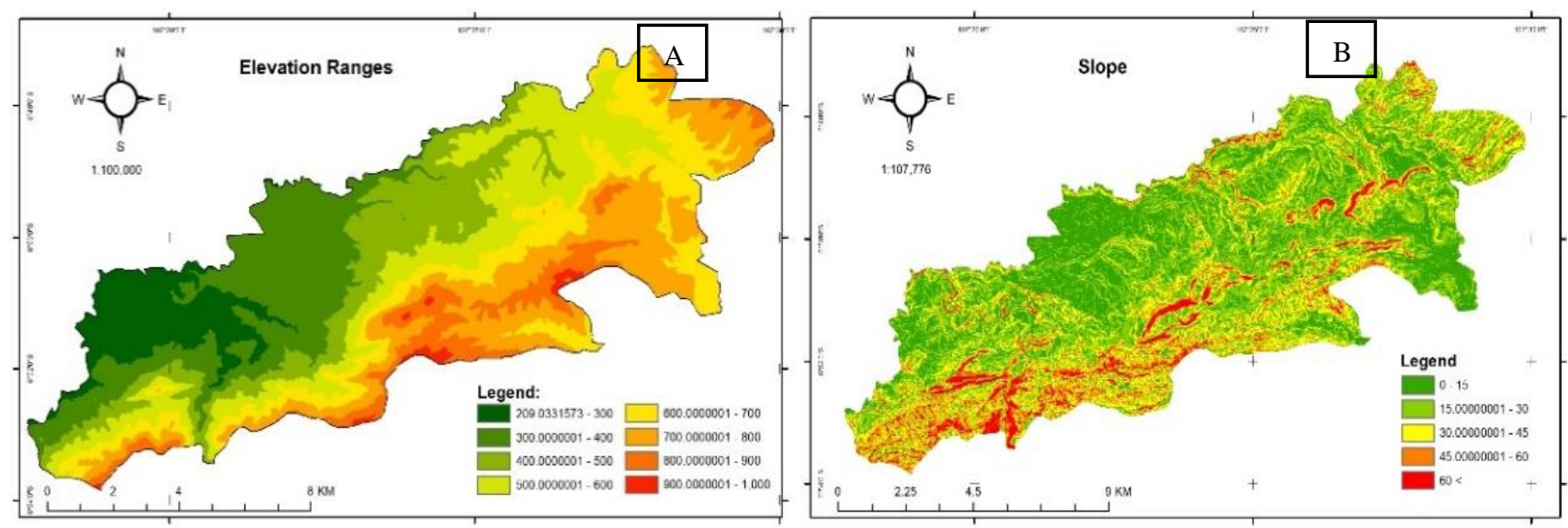

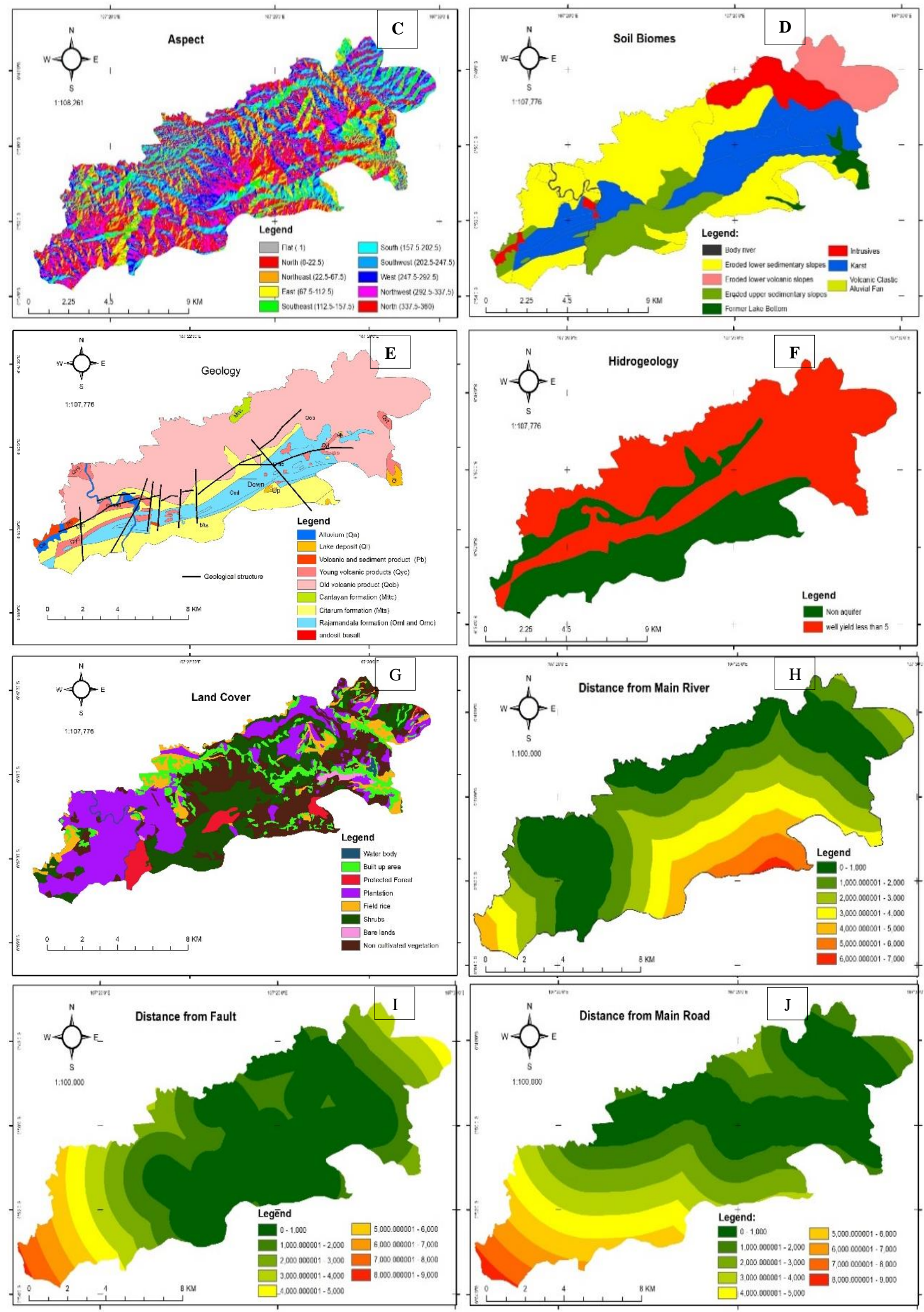

Figure 3. Ten factors for land suitability evaluation: a. elevation, b. slope, c. aspect, d. soil biomes, e. geology,

f. hydrogeology, g. land cover, h. river, i. fault, and j. main road, for land suitability analysis, the list of references in Table 3 
The weight of ten factors is assigned using AHP is presented in Table 4. Ebrahimi et al (2019) assigned higher weight on geological units and land cover, followed by slope and soil biomes, and lower weight on elevation, aspect, and groundwater. Planning Agency of West Java province (Bappeda, 2016) gives high value to natural resources and infrastructure, followed by business environmental and tourism policy. Based on this research, the highest weight is awarded lithology and land cover, then followed by the proximity to the fault and slope, followed by soil biomes, groundwater, distance to road and river, the lowest are aspect and elevation. The result of land suitability using SMCE is presented in Figure 4. The land suitability evaluation was classified into four qualitative classes based on equal interval method namely protected area $(0-0.25)$, non-suitable class $(0.25-0.5)$, an extensive area $(0.5-0.75)$, and intensive area $(0.75-1)$. The protective area is occupying about $10 \%$ of total area. The area has consisted of Citarum river body, protected forest, protected karst area, and possible protected karst area in future. The non-suitable area is $14.58 \%$ of the total area, the area is mostly the least value according to ten factors. For future development need special engineering approaches. The extensive area has the advantage of the biophysical area, however, for probably future development need an engineering approach. The intensive area is can be developed to intensified tourism in comparison to extensive tourism areas without a special engineering approach. The total area for each class is shown in Table 5.

Table 4. Pairwise comparison matrix, weights, and consistency ratio of the ten factors (Consistency ratio (CR): 0.0929)

\begin{tabular}{|l|c|c|c|c|c|c|c|c|c|c|c|}
\hline Criteria & Elevation & Slope & Aspect & $\begin{array}{c}\text { Soil } \\
\text { biomes }\end{array}$ & Lithology & $\begin{array}{c}\text { Land } \\
\text { Cover }\end{array}$ & $\begin{array}{c}\text { Ground } \\
\text { water }\end{array}$ & $\begin{array}{c}\text { Dist. } \\
\text { Road }\end{array}$ & $\begin{array}{c}\text { Dist. } \\
\text { River }\end{array}$ & $\begin{array}{c}\text { Dist. } \\
\text { Fault }\end{array}$ & Weight \\
\hline Elevation & 1.00 & 0.33 & 1.00 & 0.33 & 0.20 & 0.20 & 0.33 & 0.33 & 0.33 & 0.20 & 0.0284 \\
\hline Slope & 3.00 & 1.00 & 3.00 & 3.00 & 0.33 & 0.33 & 3.00 & 3.00 & 3.00 & 0.33 & 0.1107 \\
\hline Aspect & 1.00 & 0.33 & 1.00 & 0.33 & 0.20 & 0.20 & 0.33 & 0.33 & 1.00 & 0.33 & 0.0333 \\
\hline Soil biomes & 3.00 & 0.33 & 3.00 & 1.00 & 0.33 & 0.33 & 3.00 & 3.00 & 3.00 & 0.33 & 0.0888 \\
\hline Lithology & 5.00 & 3.00 & 5.00 & 3.00 & 1.00 & 1.00 & 3.00 & 3.00 & 5.00 & 1.00 & 0.2002 \\
\hline Land cover & 5.00 & 3.00 & 5.00 & 3.00 & 1.00 & 1.00 & 3.00 & 3.00 & 3.00 & 1.00 & 0.1902 \\
\hline Groundwater & 3.00 & 0.33 & 3.00 & 0.33 & 0.33 & 0.33 & 1.00 & 3.00 & 3.00 & 0.33 & 0.0713 \\
\hline Dist. Road & 3.00 & 0.33 & 3.00 & 0.33 & 0.33 & 0.33 & 0.33 & 1.00 & 3.00 & 0.33 & 0.0572 \\
\hline Dist. River & 3.00 & 0.33 & 1.00 & 0.33 & 0.20 & 0.33 & 0.33 & 0.33 & 1.00 & 0.33 & 0.0391 \\
\hline Dist. Fault & 5.00 & 3.00 & 3.00 & 3.00 & 1.00 & 1.00 & 3.00 & 3.00 & 3.00 & 1.00 & 0.1807 \\
\hline
\end{tabular}

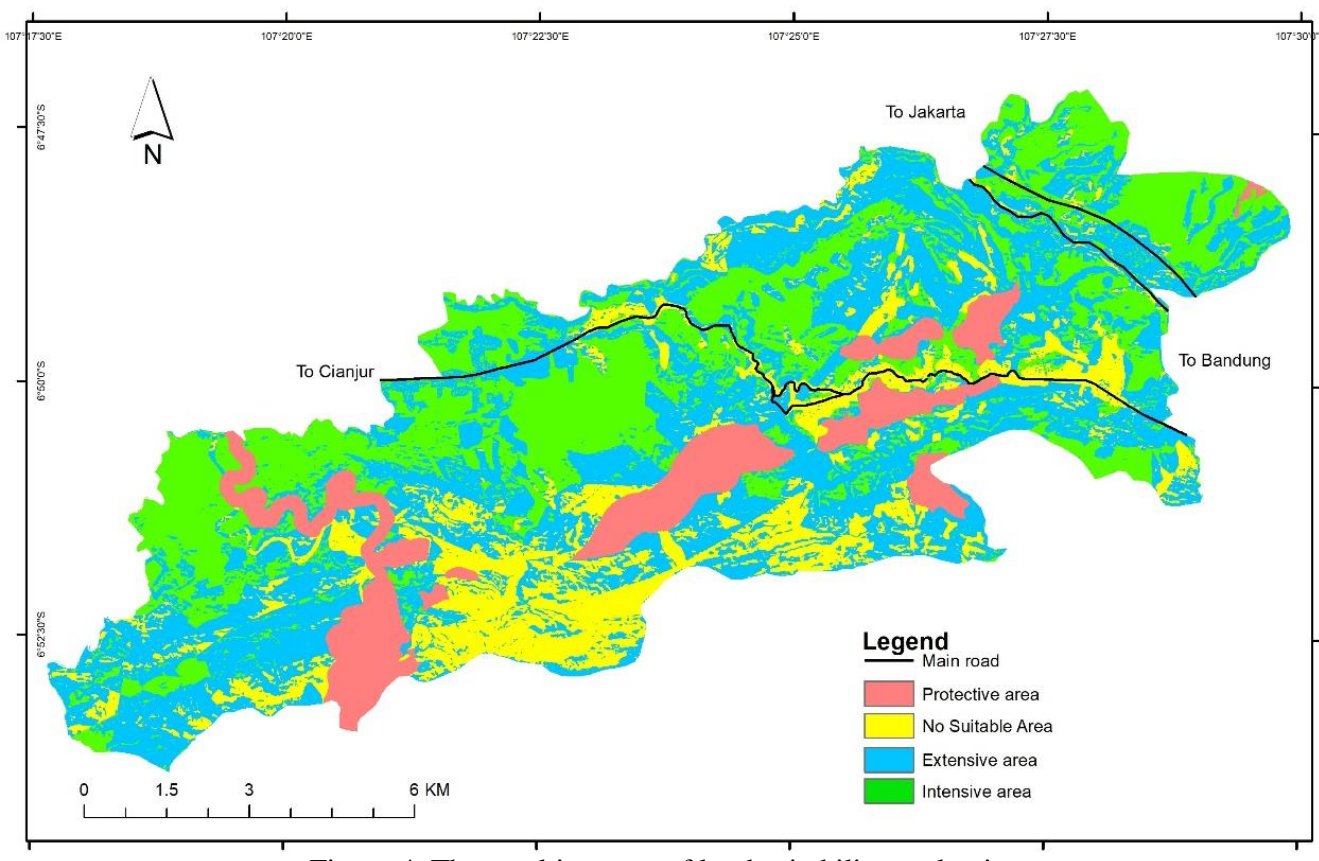

Figure 4. The resulting map of land suitability evaluation for geo-tourism in Citatah karst area using Spatial Multi Criteria Evaluation
Table 5. Distribution of four classes land suitability analysis in study area

\begin{tabular}{|l|c|c|}
\hline \multicolumn{1}{|c|}{$\begin{array}{c}\text { LSA } \\
\text { Classes }\end{array}$} & Hectare & $\begin{array}{c}\text { Proportion } \\
(\%)\end{array}$ \\
\hline $\begin{array}{l}\text { Protective } \\
\text { area }\end{array}$ & $1,279.1119$ & 10.49 \\
\hline $\begin{array}{l}\text { Intensive } \\
\text { area }\end{array}$ & $3,639.5627$ & 29.85 \\
\hline $\begin{array}{l}\text { Extensive } \\
\text { area }\end{array}$ & $5,213.8457$ & 42.76 \\
\hline $\begin{array}{l}\text { No } \\
\text { Suitable } \\
\text { area }\end{array}$ & $2,059.3679$ & 16.89 \\
\hline Total & $12,191.8883$ & 100 \\
\hline
\end{tabular}

\section{Development of Geo- tourism Area}

Future development of geo-tourism based on land suitability evaluation and assessment of existing tourism area can be divided into two areas development, namely east geo-tourism area (Citatah karst geo-tourism area) and west geo-tourism area (Citarum geo-tourism area). The assessment of present conditions is based on some aspects including geo-tourist attractions, accessibilities, tourist facilities, viewpoints and visibility of the site, safety level, and the availability of tour guides (Kubalíková, 2017).

It can be concluded that CKA has the potential to be developed as geo-tourism area, except for the safety level awareness that should be more careful since there are active mining operations, for example, the impact of hauling operation from a mining site to plant. The center of the east geo-tourism area is Citatah karst area which is dominated by extensive tourism suitable area (Figure 5). Geo-tourism can be combined with mining education-based tourism. The area has some active mining industries, and also there are geological and mining training centers, and mining research centers. Student universities from geological and mining departments usually visiting the area for field work-study. The occurrence of the site such as stone garden, stone walls for rock climbing sport (namely Citatah 48, 90, and 125), and many outcrops for geological structure study; for example, Karang panganten fault. The accessibility of area is very good since closer to the toll road than Citarum geo-tourism area. The surrounding area is very suitable to support current tourism in terms of facilities. Close to the east boundary, there are 
Ciburuy lake and a new city. The Ciburuy lake is famous for canoeing or fishing and Kota Baru Parahyangan (New City of Parahyangan) is a settlement area for middle and upper classes society that is famous for MICE, shopping, and leisure sport such as golf. Furthermore, there is a tourism awareness group, the community who can provide tour guides.

On the other hand, the center of the Citarum geo-tourism area in the western part of study is Citarum river. The area is suitable for intensive tourism because the area has advantages in terms of biophysical factor based on land suitability analysis for example, low slope, stable lithology, groundwater, and land availability (Figure 5). The uniqueness and also constraints for tourism development are the ecosystem of Citarum river and protected forest. The river in this area is very important because it is connected between two big dam; Saguling dam and Cirata dam.

To protect Citarum river is to make buffer zone from the river. Furthermore, the area of Citarum has a uniqueness of geosites including caves for example Sanghyang kenit cave, Sanghyang Tikoro, and Sanghyang Poek cave, and waterfall, for example, Halimun, Hawu, Pangulaan, Cikahuripan, and Bedil, and also hot spring of Saguling (Wulung et al, 2019; Hadian et al, 2020). Fishing, swimming, and extreme water sport (Citarum rafting) are also famous as tourist attractions. For future development in Citarum geo-tourism area, there is opportunity to combine geo-tourism with agrotourism based, since in the west boundary of study area (Cianjur) is agriculture area.

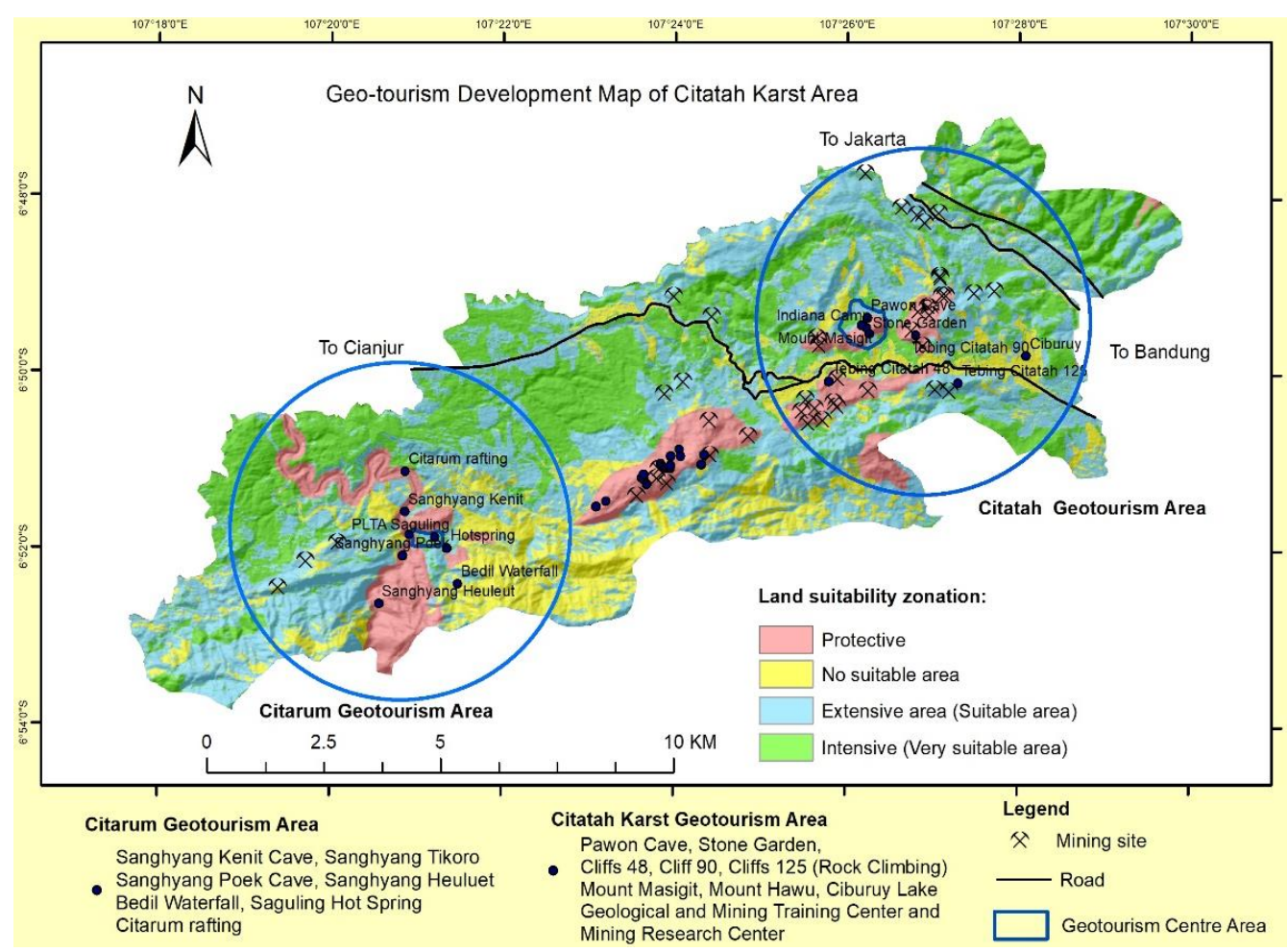

Figure 5. New development of Geo-tourism in Citatah karst area
According to the official statistic, the reason foreign tourists come to Greater Bandung is not only because of a tourist destination but also because of business. It can be expected if there is a new development area for geo-tourism will be an alternative tourism form for tourists visiting Bandung, and offer new educational experiences for tourist by introducing geological environmental aspect. Geo-tourism development must be planned comprehensively to contribute to the sustainability of geosite and the destination. In many cases, if there is no management properly will destroy the geosite or geoheritage itself. The subject of spatial multi-criteria evaluation of tourism in Indonesia is relatively new, multi-criteria evaluation is mostly for agriculture and natural disaster analysis. The future research will use any statistical approaches rather than biophysical model presentation and also need to calculate the carrying capacity of the area.

\section{CONCLUSION}

The broad concept of geo-tourism encompasses many aspects of a range of tourism activities, including transportation, accommodation, destination amenities, recreation, planning, and management. The lack of process in many aspects will lead to destroying the geosite itself.

As part of the planning process, the research uses an integrated technique of analytical hierarchy process (AHP) and geographic information system (GIS) or spatial multi-criteria evaluation (SMCE), the module in ILWIS 3.8.2 for land suitability analysis for geo-tourism in karst area. Citatah karst area has many natural and historical characteristics. Geotourism has considered sustainable tourism led to dedicated the area as a conservation area or geopark.

Preparing an effective spatial multi-criteria evaluation method and fieldwork survey is very important to have a good physical model. The final land suitability analysis is divided into four classes including protected, intensive, extensive, and non-suitable tourism areas. For further research need sensitivity analysis to see the value of each factor to the result of the analysis. The future research will use any statistical approaches rather than biophysical model presentation and also need to calculate the carrying capacity of the area.

Future development of geo-tourism areas based on land suitability evaluation and assessment of existing tourism is very useful. Land suitability evaluation using spatial multi criteria evaluation is based on ten factors as inputs layers. The assessment of present conditions is based on some aspects including geo-tourist attractions, accessibilities, tourist facilities, viewpoints and visibility of the site, safety level, and the availability of tour guides. 


\section{REFERENCES}

Aryantie, M.H., \& Suhirman. (2019). Strategi Manajemen Konflik di Kawasan Karst Citatah (Strategy of Conflict Management at Citatah Karst Area). ECOLAB, 13(2), 69-83, e-ISSN 2502-6267. (In Indonesian). http://dx.doi.org/10.20886/jklh.2019.13.2.69-83

Beierle, T.C. (2002). The Quality of Stakeholder-Based Decisions. Risk Analysis, 22(4), 739-749. https://doi.org/10.1111/0272-4332.00065

Bappeda (2016). Rencana Besar Pengembangan Destinasi Wisata Kelas Dunia Provinsi Jawa Barat. Spatial Planning Agency of West Java Province, (In Indonesian).

Bryson, J.M. (2007). What To Do When Stakeholders Matter: Stakeholder indetification and analysis techniques. Public Management Review, Taylor \& Francis Ltd, 6(1), 21-53. https://doi.org/10.1080/14719030410001675722

Cahyadi, H.S., \& Newsome, D. (2020). The post COVID-19 tourism dilemma for geoparks in Indonesia. International Journal of Geoheritage and Parks. https://doi.org/10.1016/j.ijgeop.2021.02.003

Dowling, R.K. (2011). Geotourism's Global Growth. Geoheritage Journal, 3(1), 1-13. https://doi.org/10.1007/s12371-010-0024-7

Dowling, R.K. (2013). Global Geotourism - An emerging Form of sustainable tourism. Czech Journal of Tourism, 2(2), 59-79. https://doi.org/10.2478/cjot-2013-0004

Ebrahimi, M., Nejadsoleymani, H., \& Daneshvar, M.R.M. (2019). Land suitability map and ecological carrying capacity for the recognition of touristic zones in the Kalat region, Iran: a multi-criteria analysis based on AHP and GIS. Asia-Pacific Journal of Regional Science. https://doi.org/10.1007/s41685-019-00123-w

Gorsevski, P.V., Donevska, K.R., Mitrovski, C.D., \& Frizado. J.P. (2012). Integrating multi-criteria evaluation techniques with geographic information systems for landfill site selection: A case study using ordered weighted average. Waste Management, 32, 287-296. https://doi.org/10.1016/j.wasman.2011.09.023

Gumusay, M.U., Koseoglu, G., \& Bakirman, T. (2016). An Assessment for site suitability for marina construction in Istanbul, Turkey, using GIS dan AHP multicriteria decision analysis. Environ Monit Assess (2016) 188:677. https://doi.org/ 10.1007/s10661-016-5677-5

Habibie, M.I., Noguchi, R., Shusuke, M., \& Ahamed, T. (2019). Land suitability analysis for maize production in Indonesia using satellite remote sensing and GIS-based multicriteria decision support system. GeoJournal. https://doi.org/10.1007/s10708-019-10091-5

Hadian, M.S.D., Suganda, B.R., Khadijah, U.L.S., \& Anwar, R.K. (2021). River Development As A Sustainable Geotourism With A Participatory Stakeholder Approach. GeoJournal of Tourism and Geosite, 34(1), 155-163. https://doi.org/10.30892/gtg.34120-631

Kubalíková, L. (2017). Mining landforms: An integrated approach for assessing the geotourism and geoeducational potential. Czech Journal of Tourism, 6(2), 131-154. https://doi.org/10.1515/cjot-2017-0007

Masih, M., Jozi, S., Lahijanian A.A., Danehkar, A., \& Vafaeinejad. A. (2018). Capability assessment and tourism development model verification of Haraz watershed using analytical hierarchy process (AHP). Environmental Monitoring and Assessment, 190:468. https://doi.org/10.1007/s10661-018-6823-z

Munda, G. (2004). Social multi criteria evaluation: Methodological foundations and operational consequences. Elsevier, 158 (European Journal of Operational Research), 662-677. https://doi.org/10.1016/S0377-2217(03)00369-2

Newsome, D., Dowling, R., \& Leung, Y.F. (2012). The nature and management of geotourism: A case study of two established iconic geotourism destinations. Tourism Management Perspectives, 2-3, 19-27. https://doi.org/10.1016/j.tmp.2011.12.009

Ólafsdóttir, R. (2019). Editorial, Geotourism. Geosciences, 9(48). https://doi.org/10.3390/geosciences9010 048

Ólafsdóttir, R., \& Tverijonaite, E. (2018). Review Geotourism: A Systematic Literature Review. Geosciences, 8, 234. https://doi.org/ $10.3390 /$ geosciences8070234

Pasaribu, M., Mudiana, W., \& Sunarya, Y. (1998). Hydrogeological Map of Indonesia. Directorate of Environmental Geology. Geological Agency of Indonesia.

Rahman, M.R., \& Saha, S.K. (2008). Remote sensing, spatial multi criteria evaluation (SMCE) and analytical hierarchy process (AHP) in optimal cropping pattern planning for a flood prone area. Journal of Spatial Science, 53(2), 161-177. https://doi.org/ 10.1080/14498596.2008.9635156

Rohaendi, N., Robiana, R., Sukiyah, E., Muslim, D., \& Cipta (2021). Seismic Hazard Zonation in Gedebage Future Development in Bandung City Using HVSR Inversion. International Journal on Advanced Science Engineering Information Technology. 11(3), 947954. https://doi.org/10.18517/ijaseit.11.3.14996

Ruban, D.A. (2018). Karst as Important Resource for Geopark-Based Tourism: Current State and Biases. Resources, 7(82). MDPI. https://doi.org/10.3390/resources7040082

Saaty, R.W. (1987). The analytic hierarchy process - what it is and how it is used. Mathematical Modelling, 9 (3-5), 161-176. https://doi.org/10.1016/0270-0255(87)90473-8

Sarkar, A., Ghosh, A., \& Banik, P. (2014). Multi-criteria land evaluation for suitability analysis of wheat: a case study of a watershed in eastern plateau region, India. Geospatial Information Science, 17(2), 119-128. https://doi.org/10.1080/10095020.2013.774106

Sudjatmiko (1972). Geologic map of the Cianjur quadrangle. Center of Geological Research and Development of Indonesia. Geological Agency of Indonesia.

Tarigan, A.K.M., Sagala, S., Samsura, D.A.A., Fiisabiilillah, D.F., Simarmata, H.A., \& Nababan, M. (2016). Bandung City, Indonesia. Cities. 50, 100-110. https://doi.org/10.1016/j.cities.2015.09.005

Tutic, D, Stanfel, M., \& Horvat, M.T. (2018). Multi-Criteria Land Evaluation of Suitability for the Sport of Foot Orienteering: A Case Study of Croatia and Slovenia. International Journal of Geo-Information: 7, 227. https://doi.org/10.3390/ijgi7060227

Urich, P.B. (2002). Land use in karst terrain: review of impacts of primary activities on temperate karst ecosystems. Science for Conservation 198. Published by Department of Conservation, P.O. Box 10-420 Wellington, New Zealand, ISSN 1173-2946.

Wulung, S.R.P., Adriani, Y., Brahmantyo, B., \& Rosyidie, A. (2019). Geotourism in west Bandung regency to promote citatah saguling aspiring geopark. IOP Conf. Series: Earth and Environmental Science 683 (2021) 012115 IOP Publishing. https://doi.org/ $10.1088 / 1755-1315 / 683 / 1 / 012115$

*** Geospatial Agency of Indonesia (GIA). (2020). Seamless Digital Elevation Model (DEM) and National Bathymetry of Indonesia. https://tanahair.indonesia.go.id/demnas/ 